\title{
Home Environment and Juvenile Delinquency in Nigeria: A Study of Inmates in Port Harcourt Remand Home and The Borstal Institute, Ilorin in Kware State
}

${\text { Iseberetonma, } \text { Victor }^{1^{*}} \text {, Elem, Maduawuchi }}^{2}$

${ }^{\mathrm{T}}$ Rivers State Ministry of Social Welfare and Rehabilitation

${ }^{2}$ Department of Sociology, Ignatius Ajuru University of Education, Rivers State

Article History

Received: 11.02 .2021

Accepted: 23.02.2021

Published: 07.03.2021

Journal homepage:

https://www.easpublisher.com

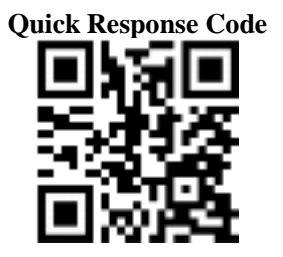

Abstract: The rising cases of juvenile delinquency have led to serious reactions to many who are concerned about the reasons for anti-social behaviours by juvenile. Thus, the study examined home environment and juvenile delinquency in Nigeria, with emphasis on Port Harcourt remand home and the borstal institute, Ilorin, Kware State. The study was guided by three research questions. The descriptive research design was used for the study. The population of study constitutes 268 inmates. Again, 100 inmates were used as sample size. The census sampling technique and random sampling technique were adopted to give inmates equal opportunities for selection. Questionnaire instrument was used for the study. The mean and standard deviation was used as method of data analysis. The findings revealed that the home environment is a major contributor to children's involvement in anti-social and delinquent behaviours. The study shows that involvement in juvenile delinquency is attributed to the socio-economic conditions of the family. Hence, the study concludes and recommended that family should endeavour to create the right atmosphere for children to grow properly in the society and the need for family based preventive and treatment measure be adopted to reduce the incidence of juvenile delinquent.

Keywords: Home Environment, Juvenile Delinquency, socio-economic.

Copyright (C) 2021 The Author(s): This is an open-access article distributed under the terms of the Creative Commons Attribution 4.0 International License (CC BY-NC 4.0) which permits unrestricted use, distribution, and reproduction in any medium for non-commercial use provided the original author and source are credited.

\subsection{BACKGROUND TO THE STUDY}

Juvenile delinquency constitutes a serious social problem which has frequently attracted universal attention and its phenomenon has been on increase [1, 2]. However, anti-social behaviours of juveniles have been posing a lot of issues to the well-being of the people of Nigeria. Thus, citizens, researchers as well as public officers posit that juvenile delinquency is a serious social modern problem in Nigeria. For many young ones today, the traditional blueprints guiding the relationship and traditions between among family, school and work are being challenged. Some youths hold on to juvenile crimes and anti-social behaviours. This includes drug abuse, prostitution, bulling, truancy examination malpractice, theft and cultism [3, 4]. The child's home plays a significant role in his or her life. The reason for the above assertion is because the child starts his life journey from the home. Therefore, the child's home is his primary contact with the external world coming out from the womb and so whatever he sees or experiences in the home influences and also has the capability to rebrand his life for good or bad, positively or negatively.

There exist a variety of studies by scholars which reveals that home environment constitutes a contributing factor to juvenile delinquency for example, the number of people in a family, family problems, inconsistent parenting, child neglect and the children's attachment to parents $[5,16]$. Some researchers such as Okpuko 2004 [7] and Ofliadah 2008, as cited in Animashun and Aremu [6] reveals that the population of adolescent delinquently is rooted in the type of home the adolescent is brought up. In addition, Conger [8] as cited in Animasahun and Aremu [6] revealed that when guardian or parents are responsive and when deep love is present, delinquency desistance is much more significant than when only one of these factors is present. Thus, the child's environment differs in various ways. For instance, differences can be seen in the socio economic status, education, parenting style and skills exhibited, show of affection, communication patterns in the family etc. This will now enable us to understand the kind of home environment that is likely to breed a delinquent because various research have indicated that juvenile delinquency is rooted in the kind of home the child is brought up Igbo 2007 as cited in Ugwuoke and Duruji [2]; Adegoke [9] as cited in Akinlotan, Ojo, Abisoye, Ama, and Edegbai [10]. Hence, an extrapolation from this study, it aims at investigating the relationship between home environment and juvenile delinquency in Nigeria with emphasis on the inmates of Port Harcourt Remand Home and the Borstal institute, Ilorin in Kware State. 


\subsection{STATEMENT OF THE PROBLEM}

Juvenile delinquency constitutes very serious social problem in Nigeria and indeed Rivers State and Kwara State. It has attracted a great attention in these areas and beyond. This has led to serious menace to development for the adolescents, youths and the entire society. Many of the adolescent or youth are deeply involved in ferocious crimes, armed robbery, murder, theft, possession of dangerous weapons like guns, knives, cultism, kidnapping, prostitution gang initiations, raping and involvement as political thugs drug trafficking and hired assassins. As youths are arrested by the security or law enforcement outfit, they are charged to court whether juvenile or adults court to stand trials for offences they are charge with. If the victim is found guilty, they are taken to the remand home for confinement for a period of time. Reacting to this fact, the $1 \mathrm{mo}$ State commander of National Drug Law Enforcement Agency (NDLEA) lamented that most youth are deeply involved in illicit drug usage and misuse, Ugwuoke and Duruji, [2] citing Nwopara, 2011.

Again, Nwachukwu [11], Adegoke [9] Animasahun and Aremu [6], Ugwuoke and Duruji [2] confirm to the influence of home environment on juvenile delinquency or anti-social behaviour in Owerri, Osun, Lagos and Asaba. In this case, Port Harcourt is not isolated from this problem. According to 2016 Port Harcourt Remand Home report inmate record, 45 individuals were brought into the Port Harcourt Remand Home. In 2017, 51 persons were brought into the home.

Thirty five (35) inmates in 2015 were brought within six months, while in 2013 and 2014 respectively, 40 and 13 inmates were remanded respectively within 3 months' time. This is also applicable to Ilorin where the Borstal institute is located. It also has its share of juvenile problems. It was recorded that as at February, 2020, there were about 224 inmates in the institution. Considering this increase in population, the home environment constitutes a responsible factor. Regrettably, these established institutions of juvenile correction are now being overstretched beyond their capacity to the extent that instead of being a correctional institution for children and it is now like a breeding ground for future criminals. As a result, these children who are potential future leaders of their generation or resource persons to fast track development will be lost. Having observed this, government, churches, and NGOs should embark on programs on the need for parents to build a good home, be adverse to broken homes or divorce, polygamy, having of few children as your income can carry, and the empowerment of the family.

In spite of these efforts, there is rising incidence of Juvenile delinquency due to home environment. For example, according to reports from both institutions, most of the inmates upon admittance when interviewed specify on the influence of the home environment to their predicament. And so it does appear as if the more efforts are made to solve the problem, the more the incident rate increases. Scholars such as Nwachukwu [11], Animasahun and Aremu [12], Adegoka [9] Ugwoke and Duruji [2] agree that low family income broken home, single parenthood, criminal parents etc. are the primary cause of delinquency and anti-social behaviours. Instead of this problem decreasing, it is rather on the increase and this is attested to by various scholars like Adegoke [9], Edet 2010 as cited in Ajah and Ugwuoke [3], Daudu [13] as cited in Ajah and Ugwuoke [3], and Ajah and Ugwuoke, 2018 [3] in their different studies revealed that the manifestation of juvenile delinquency report are on the increase. The scholars through their studies reveals that, this increase can be linked to certain variables in the home environment such as inadequate parental supervision, divorce, lack or poor parental skills, , rejection or children, broken home, poverty, unstable homes, parental age, pampering of children, single parent homes and many more, are responsible. An extrapolation from the cited scholarly works none focused attention on Port Harcourt Remand Home and the Borstal Institute and the influence of home environment to juvenile cases. The paper will be guided under the following posited questions:

i. How can one establish if juvenile delinquency exists and if it is caused by home environment in the areas of study?

ii. What is the rationale for the increase in juvenile delinquency and the rising incidence of juvenile inmates in the areas of study?

iii. What are the measures that will be taken to reduce the incidence of juvenile delinquency through reduction in negative family influences in the areas of this study?

\subsection{METHODOLOGY}

The descriptive research design was adopted in the study. The study was carried out at the Port Harcourt Remand Home in the Rivers State and the Borstal Institute, Ilorin at Kware State. Both of these institutions are juvenile correctional facilities to reform and rehabilitate juvenile that are considered to have violated societal laws. The population of the study is made up of the inmates of two institutions of juvenile 
correction which are the Port Harcourt Remand Home and the Borstal Institute, Ilorin. There are 268 inmates in both facilities. The Borstal institute has 224 inmates while the Port Harcourt Remand Home has 42 inmates. The sample size is made up of all the inmates forty two (42) in Port Harcourt remand home and 58 inmates from the Borstal institute, 1lorinjn, Kwara State. The total of 100 inmates drawn from both institutions was used for the study. For the inmates at Port Harcourt Remand Home, the researchers used the Census Sampling Technique since all the population available was used. For the inmates at Borstal Institute, the Random Sampling Technique was adopted which gives all the inmates an equal opportunity to be chosen for the study. The instrument for the study is questionnaire. Statistically, the mean and standard deviation was used to analyse the research questions.

\subsection{LITERATURE REVIEW}

In the view of Izuchi and Wayobuije [10], home environment is seen as the characteristic features of the family including within-house and the immediate neighbourhood within which the child lives. It involves both an expression of the identity of the family and the expression of physical translation of behaviors, practices, educational and traditional beliefs. The environment wherein the children live, grow and are groomed play a very important part to them conforming to the standards set by the society. In another view, Balda, Sungwan and Kumari [14], posited that the home (family) environment entails the quality and quantity of socio-emotional support as well as the understanding that parents provide to their children within the home. It can be seen from these definitions and interpretations that the home environment and family environment are used to mean one and the something depending on the usage of the writer.). It should be obvious that the home environment constitutes a collection of little environmental processes which affect other behaviours. Family as the prime unit and a significant agent of socialization witness interactions among family members and these interactions are called transactions.
These transactions can breed positive or negative outcomes.

The concept of juvenile delinquency according to scholars constituted a social construct. It was a product of many different political, religious, economic and social changes. Hence, a juvenile is a child who is being considered to have gone against the criminal laws of his or her nation and whose acts have been declared an offense. Therefore, age is a determining factor in considering who a juvenile is, and so most countries of the world consider a person under the age of 21 years to be a juvenile [19], On the other hand, the term 'delinquency' is applied to children who are engaged in unlawful, anti-social and dangerous behaviors and lifestyles.

According to World Youth Report [1], the concept of juvenile delinquency can be understood from various Perspectives. In the view of Social workers, they believe that juvenile delinquency is made up of socially unaccepted acts that are antithetical for societal growth. As for the Sociologists, it revealed that juvenile delinquency is made up of different forms of violation of legal and social norms from negligible to grave offences. Also, Criminologists perceived juvenile delinquency as the any public wrongs perpetuated by persons between the age range of 12 and 20 years. To the psychiatrist juvenile delinquency involves behaviors or activities which deviate from normal practice and standard in the society. To the legal practitioner, juvenile delinquency is what the law say it is. Given the above assertion, the concept of juvenile delinquency refers to all behaviours, activities, acts, lifestyles which a child or a person who is not considered to an adult usually defined by a country's law commit and it is considered as an offence and punishable under the nation's law of that country.

\subsection{PRESENTATION OF DATA}

Research question one: How can one establish if juvenile delinquency exists and is caused by home environment in the area of study? 
Iseberetonma, Victor \& Elem, Maduawuchi; EAS J Humanit Cult Stud; Vol-3: Iss-2 (Mar-Apr, 2021): 70-78

Table-1: presents the summary of descriptive statistic on how one establishes if juvenile delinquency exists and it is caused by home environment in the area of study

\begin{tabular}{|l|l|l|l|l|l|l|l|}
\hline $\mathbf{S} / \mathbf{N}$ & ITEMS & SA & $\mathbf{A}$ & $\mathbf{D}$ & SD & MEAN & SD \\
\hline $\mathbf{1}$ & $\begin{array}{l}\text { Juveniles are involved in deviant behaviours such as stealing, cultism } \\
\text { etc. }\end{array}$ & $\mathbf{6 6}$ & $\mathbf{1 9}$ & $\mathbf{1 2}$ & $\mathbf{3}$ & $\mathbf{3 . 4 8}$ & $\mathbf{0 . 8 2}$ \\
\hline $\mathbf{2}$ & Juveniles are arrested by the police and other law enforcement agents & 36 & 51 & 10 & 3 & 3.20 & 0.74 \\
\hline $\mathbf{3}$ & Juveniles are prosecuted in courts for various offences & 22 & 44 & 29 & 5 & 2.83 & 0.83 \\
\hline $\mathbf{4}$ & $\begin{array}{l}\text { Juveniles are remanded in institutions of juvenile correction for } \\
\text { various offences. }\end{array}$ & 34 & 25 & 24 & 17 & 2.76 & 1.10 \\
\hline $\mathbf{5}$ & $\begin{array}{l}\text { Children engaged in delinquent behaviours because their parents are } \\
\text { poor }\end{array}$ & 27 & 49 & 13 & 11 & 2.92 & 0.92 \\
\hline $\mathbf{6}$ & $\begin{array}{l}\text { Children are involved in anti-social behaviours because they are from } \\
\text { broken homes }\end{array}$ & 29 & 25 & 27 & 19 & 2.64 & 1.10 \\
\hline $\mathbf{7}$ & $\begin{array}{l}\text { Juveniles engage in violent behaviours because they see their parents } \\
\text { fighting }\end{array}$ & 24 & 30 & 33 & 13 & 2.65 & 0.99 \\
\hline $\mathbf{8}$ & $\begin{array}{l}\text { Children engage in delinquent behaviours because of poor discipline } \\
\text { at home. }\end{array}$ & 39 & 32 & 19 & 10 & 3.00 & 0.99 \\
\hline $\mathbf{9}$ & Children engage in anti-social behaviour because of poor training. & 30 & 37 & 23 & 10 & 2.87 & 0.96 \\
\hline $\mathbf{1 0}$ & $\begin{array}{l}\text { Juveniles engaged in deviant behaviour because of poor training and } \\
\text { up bring }\end{array}$ & 44 & 24 & 16 & 16 & 2.96 & 0.12 \\
\hline & Grand Mean & & & & & $\mathbf{2 . 9 3}$ & $\mathbf{0 . 3 3}$ \\
\hline
\end{tabular}

\section{Source: Field Work 2021}

The result from table 1 shows the summary of descriptive statistic on how one establish if juvenile delinquency exists and it is caused by home environment in the area of study. It shows that the grand mean rating of the respondents was 2.93, $\mathrm{SD}=0.33$. Specifically, the respondents indicated that juveniles are involved in deviant behaviours such as stealing, cultism etc with a mean rating of 3.48 , $\mathrm{SD}=0.82$. This was followed by the fact that juveniles are arrested by the police and other law enforcement agents with the mean rating of $3.20, \mathrm{SD}=0.74$. Children engage in delinquent behaviours because of poor discipline at home had mean rating of $3.00, \mathrm{SD}=0.99$.
Juveniles engaged in deviant behaviour because of poor training and upbringing had mean rating of 2.96, $\mathrm{SD}=1.12$. Children engaged in delinquent behaviours because their parents are poor had rating of 2.92, $\mathrm{SD}=0.92$. Children engage in anti-social behaviour because of lack of affection at home had mean rating of 2.87, $\mathrm{SD}=0.96$. Juveniles are prosecuted in courts for various offence had mean rating of $2.83, \mathrm{SD}=0.83$

Research Question 2: what is the rationale for the increase in juvenile delinquency and the rising of juvenile inmates in the area of study?

Table-2: Presents summary of descriptive statistic on the rationale for the increase in juvenile delinquency and the rising of juvenile inmates in the area of study.

\begin{tabular}{|l|l|l|l|l|l|l|l|}
\hline S/N & ITEMS & SA & A & D & SD & MEAN & SD \\
\hline 1 & Inadequacy of institutions established to reform juvenile offenders. & 51 & 23 & 20 & 6 & 3.19 & 0.96 \\
\hline 2 & Poor neighbourhood /environment/slums & 32 & 47 & 16 & 5 & 3.06 & 0.83 \\
\hline 3 & Peer pressure and influence of friends & 35 & 27 & 26 & 12 & 2.86 & 1.04 \\
\hline 4 & Lack of awareness of the existence of juvenile justice services by public & 16 & 27 & 42 & 15 & 2.44 & 0.94 \\
\hline 5 & $\begin{array}{l}\text { Lack of awareness existing law promulgated to safe guard the fundamental } \\
\text { rights of children. }\end{array}$ & 31 & 45 & 18 & 6 & 3.01 & 0.86 \\
\hline 6 & Poor socio-economic status of parents & 34 & 39 & 23 & 4 & 3.03 & 0.86 \\
\hline 7 & Lack of child rearing and parenting skills & 40 & 27 & 22 & 11 & 2.96 & 1.03 \\
\hline 8 & $\begin{array}{l}\text { The difficulty of parents and guardian to adequately take care of their } \\
\text { children }\end{array}$ & 34 & 42 & 12 & 12 & 2.98 & 0.97 \\
\hline 9 & $\begin{array}{l}\text { Exposure of children to unwarranted hardship like hawking at their } \\
\text { formative ages. }\end{array}$ & 46 & 30 & 18 & 6 & 3.16 & 0.93 \\
\hline 10 & Negative influence of watching films and movies. & 33 & 35 & 19 & 13 & 2.88 & 1.02 \\
\hline & Grand Mean & & & $\mathbf{2 . 9 6}$ & $\mathbf{0 . 3 3}$ \\
\hline
\end{tabular}

Source: Field Work 2020 
The result from table 2 shows the summary of descriptive statistic on the rationale for the increase in juvenile delinquency and the rising incidence of juvenile inmates in the area of study. It shows that the grand mean rating of the respondents over rationale for the increase in juvenile delinquency and the rising incidence of juvenile inmates in the area of study was 2.95, $\mathrm{SD}=0.33$. Specifically, the respondents indicated that inadequacy of institution established to reform juvenile offenders was a rationale with a mean rating of $3.19, \mathrm{SD}=0.96$. This was followed by the exposure of children to unwarranted hardship like hawking at their formative ages which had a mean rating of 3.16,
$\mathrm{SD}=0.93$. Poor neighbour/environment/slums had a mean rating of $3.06, \mathrm{SD}=0.83$, poor socio-economic status of parents had mean rating of $3.03, \mathrm{SD}=0.86$, lack of awareness existing law promulgated to safeguard the fundamental rights of children had mean rating of 3.01, $\mathrm{SD}=0.86$ and the difficulty of parents and guardian to adequately take care of their children had mean rating of $2.98, \mathrm{SD}=0.97$ among others.

Research Question 3: what are the measures that will be taken to reduce the incidence of juvenile delinquency through reduction in negative family influences in the area of this study?

Table-3: Presents summary of descriptive statistic on the measures that will be taken to reduce the incidence of juvenile delinquency through reduction in negative family influences in the area of this study

\begin{tabular}{|l|l|l|l|l|l|l|l|}
\hline S/N & ITEMS & SA & A & D & SD & MEAN & SD \\
\hline 1 & Training of parents in family management techniques. & 68 & 21 & 6 & 5 & 3.52 & 0.82 \\
\hline 2 & Family programmes/interventions to reduce family poverty & 40 & 42 & 15 & 3 & 3.19 & 0.80 \\
\hline 3 & Discouraging divorce and broken home by every means possible. & 46 & 30 & 14 & 10 & 3.12 & 1.00 \\
\hline 4 & Encouraging parents to display good character and moral integrity. & 43 & 22 & 24 & 11 & 2.97 & 1.06 \\
\hline 5 & $\begin{array}{l}\text { Encouraging parents to train their children to imbibe the proper values } \\
\text { and norms of the society }\end{array}$ & 31 & 32 & 22 & 15 & 2.79 & 1.05 \\
\hline 6 & $\begin{array}{l}\text { Parents should endeavour to provide the basic necessities in the } \\
\text { family. }\end{array}$ & 39 & 32 & 21 & 8 & 3.02 & 0.96 \\
\hline 7 & $\begin{array}{l}\text { Parents should show love and affection for their children } \\
\text { along their natural talents, gifting, and interests in life. }\end{array}$ & 45 & 28 & 15 & 12 & 3.06 & 1.04 \\
\hline 8 & $\begin{array}{l}\text { Parents should accept and support their children to grow and develop } \\
\text { parents should avoid unnecessary comparison of their children to other } \\
\text { children }\end{array}$ & 38 & 43 & 9 & 9 & 3.38 & 0.98 \\
\hline 9 & $\begin{array}{l}\text { Parents should provide proper discipline and consciously make } \\
\text { improvements in family communication. }\end{array}$ & 48 & 13 & 20 & 19 & 2.90 & 1.20 \\
\hline & Grand Mean & & & & $\mathbf{3 . 1 1}$ & $\mathbf{0 . 4 8}$ \\
\hline
\end{tabular}

Source: Field Work 2021

The result from table 3 shows the summary of descriptive statistic on the measures that will be taken to reduce the incidence of juvenile delinquency through reduction in negative family influences in the area of the study. It shows that the measures that will be taken to reduce the incidence of juvenile delinquency through reduction in negative family influences in the area of this study had a grand mean rating of $3.11, \mathrm{SD}=0.48$. Specifically, the result showed that training of parents in family management techniques had mean rating of 3.52, $\mathrm{SD}=0.82$. This was followed by the fact that parents should accept and support their children to grow and develop along their natural talent, gifting, and interests in life which had a mean rating of 3.38 , $\mathrm{SD}=0.98$. Family programmes/interventions to reduce family poverty had mean rating of $3.19, \mathrm{SD}=0.80$. Parents should avoid unnecessary comparison of their children to other children which had a mean rating of 3 . $14, \mathrm{SD}=0.84$ and discouraging divorced and broken home by every means possible had mean rating of 3.12, $\mathrm{SD}=1.00$ among others.

\subsection{DISCUSSION OF FINDINGS}

How can one establish if juvenile delinquency exists and if it is caused by home environment in the work of study?

From the data analysis, it is obvious that juvenile delinquency exists and is caused by home environment in the work of study. According to Nwachukwu [11] juvenile delinquency does exist. This is because of the involvement of children in various kinds of delinquent and anti-social behaviours such as truancy, unwanted pregnancy, stealing, disobedience, examination malpractice, substance abuse, lying and 
bulling. This then shows that the problem of juvenile delinquency is real in the society. This finding authenticates Agbowuro, Taiwo, Umeh and Solomon [13] work on the dilemma of juvenile delinquency among government secondary schools in Jema'a Local Government Area of Kaduna State, Nigeria. It thus suggests that the issue of juvenile delinquency is a concern in the society. In addressing this concern, children involved in juvenile delinquency are arrested by the police and other law enforcement agents [15]. In their study of juvenile justice administration, it was shown that there were so many children who had been arrested and detained in various police cells across the country for various juvenile offences such as theft, fraud, robbery, burglary, assault, fighting rape, demonstration, rioting, and beyond parental control. In that same study, it was observed that children were arraigned in court for various offences such as those mentioned above in different courts across the country.

Also, Ugwuoke and Duruji [2] in their study noted that the family environment should be held accountable for children's involvement in ant-social and delinquent behaviours. Specifically, the study noted that children who come from unstable homes are more likely to be involved in anti-social behaviours than their peers who grow up in stable homes; the study also indicated inadequate parental supervision of children can lead to anti-social behavior in children. Family instability can also be seen as broken homes, corroborating this finding, Adegoke 2015 [9] in his finding observed that broken homes is a major factor in the family which contributes to anti-social behaviours in the life of children.

Another factor the study noticed was that poverty in the family can contribute to children engaging in juvenile delinquency. Poverty is a situation in the family where the family is unable to meet with the basic necessities of life such as life, shelter, clothing, education and medical needs of the family, particularly the children. This is exactly the finding of Akinlotan, Ojo, Abisoye, Ama and Edegbal [10] on an opinion survey on social-economic factors of juvenile delinquency in Ketu-Adie, Owu Community in Ogun State. In this work it was revealed that $97.2 \%$ of the respondents agreed that poverty is a strong contributor to juvenile delinquency. The study also showed that 83.3\% confirmed that low family income is a great contributor to children engaging in anti-social behaviours. This shows that the lack of purchasing power (money) in the family is a major problem in the family as its lack deprives parents from being able to provide for the needs of the children. Therefore, denying the children from certain privileges and exposing them to negative influence in the society. In that same study, it was discovered that $89.0 \%$ of the respondents indicated that broken home is responsible for juvenile delinquency which agrees with the findings of Ugwuoke and Duruji [2] and Adejoke [9] cited earlier. $84.5 \%$ of respondents in that same study also revealed that lack of parental control is a contributor to children involvement in anti-social and delinquent lifestyle. In essence, the various findings discussed shows that juvenile delinquency does exist in the society. It is also showed that the home environment is a major contributor to children's involvement in antisocial and delinquent behaviours. Therefore, there is a relationship between the home environment and juvenile delinquency.

\section{What is the rationale for the increase in juvenile delinquency and the increasing incidence of juvenile inmates in the area of study?}

The result from the study indicates that there is a rationale for the increase in juvenile delinquency and the increasing incidence of juvenile inmates. According to Alemika and Chukwuma [15] the Juvenile Justice Agencies and Institutions in Nigeria which is made up of the Police, Courts, Remand Homes, Approved Schools and the Borstal Institutions are lacking in adequate and qualified staff that are able to meet the needs, concerns and aspirations of juvenile offenders. This shows that the Nigerian society has failed in its responsibility towards providing a favourable environment for the right of the child to be protected and the welfare and development of the young person. Corroborating this findings, Zakari [16] in his study observed that the examination of the Nigerian Police Force, The Court-Juvenile/Family Courts.

The remand homes, approved schools and Borstal institution show structural and operational problems facing these agencies in the discharge of their statutory functions across the country. The study showed that these agencies are lacking basic facilities and appropriate knowledge and training to enable them correctly carryout the provision of the laws protecting children and seeking to protect the rights of the child when in conflict with the extant laws of the land. This is also the position of Ekpenyong, Raimi and Ekpenyong [17] in their study of urban poverty and juvenile delinquency in Nigeria; through the lens of Port Harcourt remand home inmates. One of the findings showed that the remand home is poorly equipped to take care of juvenile offenders which make the rehabilitation of the inmates very difficult to achieve. In carryout comparative analysis of juvenile justice system 
in the northern and southern part on Nigeria, Mboho and Udousoro observed that there exists a dysfunctional juvenile justice system in Nigeria both in the northern and southern parts. The various institutions of juvenile correction are ill-equipped and therefore cannot carry out their statutory functions. All these create more problems for juvenile offenders because the purpose of being in such institutions of rehabilitation and reformation will be defeated. It is on this ground that Ajah and Ugwuoke [3] argued that as a result of the increase in crime rate by young offenders and the failure of the juvenile correctional institutions to reform these children, according to expectations. The result is that these children and young offenders instead of being reformed and rehabilitated become hardened and more criminal minded after being to this institution. This means that the failure of the agencies saddled with the responsibility to reform, rehabilitate these young offenders in it throws the juvenile offenders back to the society to commit more offences. This is like carrying out vengeance against the society.

Another reason for the increase in juvenile delinquency as indicated from the study is attributed to the socio-economic conditions in the family. According to Ugwu [2], parent's socio-economic position bears heavily on adolescent delinquent behavior. The economic class adolescents belong to can determine their behavior at any given time. Children who come from affluent families because of the money at their disposal maybe involved in behaviours like clubbing, partying, smoking and substance abuse. It could also be explained that children from low socio-economic families also indulge in delinquent behavior. This could be because of lack of money and social position may get involved in stealing, prostitution, shoplifting etc. to help themselves. This is exactly the position of Ekpo and Ajake [7] that the financial position of child's parents contributes a lot to delinquent bahaviour. They observed that children from low socio-economic background and more likely to indulge in delinquent behaviours than children from high socio-economic background. In other words, when children's needs such as foods, clothing, etc cannot be met in the family because of financial difficulties, there are the tendencies for the children to look elsewhere for help. And this may lead to stealing, prostitution and other criminal activities and the like. For this class of persons, in an attempt to improve the socio-economic conditions of the family sees hawking and street trading as a way out. So parents send their children out on the streets to trade and before they know it their children have developed delinquent behaviours.
Another reason identified by the study which leads to increase in juvenile delinquency is because of the failure of parents to properly supervise and monitor their children. Parents who properly monitor and supervise their children are aware of what their children are doing, friends they play with, where they are. This is in agreement with the findings of Ojo, Akinilotän, Edegbal, Abisoye and Olaniyi [10] in their study wherein $89.9 \%$ or respondents indicated that lack of parental supervision is a contributor to juvenile delinquency. This confirms the findings of Umair and Azka [18] wherein they noted that parent's failure to properly monitor and supervise their children's behavior could be seen in the kind of films their children watch. When parents properly supervise and monitor the content of what their children are watching on television the children will be well guided but when the parents fail, the children will develop negative behavior. And this work show that watching films with negative contents leads to anti-social behavior.

\section{What are the measures that will be taken to reduce the incidence of juvenile delinquency through reduction in negative family influences in the area of study?}

The study indicated that inmates were positively inclined to measures that will reduce the incident of juvenile delinquency through the reduction in negative family influences. The family been the training ground for children, it is important to reduce negative influences in the home so that the inclination of children to go into a life of delinquency will be reduced to the bearest minimum. This is exactly the position of Uk essay 2018 on prevention and treatment of juvenile delinquency. It noted that there should be focus on training parents in family management techniques. Accordingly, the family based management involves providing skills to parents to enable them properly supervise and train their children. Developing strategies to increase family communication skills and family interaction is imperative and constitutes an effective measure. This is supported by the findings of Petrosino, Derzon and Lavanberg [8] whose study supported family based interactions and treatment for juvenile offenders. This is because when the capacity of the family is developed and improved, it will lead to reduction in crime rate in the society. This will help reduce the money been used to arrest, prosecute, incarcerate and take care of juvenile offenders by the state. When we invest in successful delinquency prevention and treatment policies that are family based, the state will have more money to carry out developmental programs. 


\subsection{CONCLUSION/ RECOMMENDATIONS}

The aim of this research was to find out how home environment influences juvenile delinquency among inmates of Port Harcourt remand home. Specifically, empirical findings revealed juvenile delinquency exist and were attributed to the home environment, especially those with negative family attributes. These negative family attributes are parental poverty, broken home, poor supervision and monitoring of children's behavior, witnessing of fighting and violence of home, criminal' parents, child maltreatment and abuse etc. finding also revealed that reduction of the negative influences in the family appears to be the most appropriate measure to reduce the incidence of juvenile delinquency in the area of study. It is therefore obvious that a healthy home environment is a very critical factor needed to keep children away from antisocial and delinquent behaviours. Given the findings and conclusion, this study recommends the following:

- The home plays a critical role to the development of the child. The family as it were is the first place the child learns the values and norms of the society. Therefore, the family should endeavour to create the right atmosphere for children to grow properly in the society. This can be achieved when parents develop good relationship with their children as they unconditionally love, care and show concern for the wellbeing of their children. Parent should also be careful with what they say and do in the presence of their children. Since, children by nature learn by observation, imitation and modelling behaviours seen exhibited by adults, parent should maintain proper conduct before their children at all times to discourage their children involving imitating wrong behaviour. Parents should not fight, quarrel or abuse themselves before their children. It would not be in the best interest of children to see their parents involved in criminal activities because of the likely negative influence it would have on the behaviour on the children. Again, parents should try and live according to their income. When they to this they would not expose their children to delicate and compromising situations like street trading and hawking which exposes them to anti-social and delinquent behaviour like prostitution, pickpocketing and substance abuse. It is therefore, incumbent on the family to providing the right atmosphere in the home to discourage children from engaging in delinquent and anti-social behaviours because the home is the training ground for the leaders of tomorrow.
- On the part of government and society, institutions of juvenile correction like the police, courts, remand homes, approved schools and Borstal Institutions that are established to control, check and curb the negative behaviour of children should be properly staffed, funded and equipped. When these institutions are strengthened in their capacity to function as established, they will be well positioned to reform, rehabilitate and reintegrate juvenile offenders in the society. Again efforts should be made by government to bring into awareness the laws, convention and protocols enacted to protect the rights of children efforts should also be made to enforce these laws, conventions and protocols when there is violation.

- $\quad$ Finally, family based preventive and treatment measure should be adopted to reduce the incidence of juvenile delinquent in the area of study. This can be done through the process of organizing programs to equipped parents and family members with the skills and tools for better family management. When negative family influences such as poor parenting skills, poor family finances, poor marital relationship etc are addressed, it will lead to better family set up. This will eventually reduce the level of delinquent and anti-social behaviors in the society. Thereby reducing the pain and anguish, the problem of juvenile delinquency caused to the entire society.

\section{REFERENCES}

1. World Youth Report. (2003). Juvenile delinquency, 189-211.

2. Ugwuoke, C.U., \& Duruji, O.U. (2015). Family instability and juvenile delinquency in Nigeria: A study of Owerri municipality. 1OSR Journal of Humanities and Social Sciences (lOS. LHSS), 20(I), 40-45.

3. Ajah, B. O., \& Ugwuoke, C. 0. (2018). Juvenile justice administration and child prisoners in Nigeria. International Journal of Criminal Justice Sciences (IJCJS), 13(2), 43 8-446.

4. Sanni, K.B., Udo, A.N., Okedije, A.A., Modo, R.N., \& Eleh, L.N. (2010). Fanily types and juvenile delinquency issues among secondary school students in Akwa Thom State, Nigeria: Counselling Implications. T Soc. Sci, 23(1), 21-28.

5. Petrosino, A., Derzon, J., \& Havenberg, J. (2009). The role of the family in crime and delinquency. Evidence from prior Quantitative Reviews. Southwest Journal of Criminal Justice, 6(2-), 108 132.

6. Animasahun, R. A., \& Aremu., C.A. (2015). Corelational study of age, family warmth and school connectedness as factors affecting secondary 
school adolescents in Osun State. Nigeria International Journal of Psychological and Behavioüral Sciences, 5(2), 30-88.

7. Ekpo, T., \& Ajaku, U. (2013). Family socioeconomic status and delinquency among senior secondary school students in Calábar South, Cross River State, Nigeria. American International Journal of Contemporary Research, 3(4).

8. Conger, R. D. (1976). Social control and social learning models of delinquent behavior a synthesis. Criminology, 14(1), 17-40.

9. Adegoke, H. (2015). Factors responsible for juvenile delinquency in Nigeria: A case study of selected primary school in Ikorodu, Lagos State, Nigeria. Research on Humanities and Social Sciences, 5(5); 78-84.

10. Akinlotan, R.A., Ojo, M.O.D., Abisoye, A.O., Ama, O. A., \& Edegbai, M.A. (2017). Opinion survey on socio-economic factors or juvenile delinquency in Ketu- Adie 0wu community in Ogun State. International Journal of Social and Management Sciences, Madonna University (IJSMS), 1(I), 139-153.

11. Nwachukwu, U. (2018). Juvenile infraction in selected secondary schools in Asaba, Delta State, Nigeria. International Journal of Scientific Research in Education, 11(3 B), 529-544.

12. Amalu, M., M. (2017). Family Environment and self-esteem as predictors of psychological Adjustment of secondary school students from divorced homes in Cross Rivers State, Nigeria, 7(6), 09-16.
13. Agbowuro, C. Taiwo. 0. L., Umeh M. M., \& Solomon, S. (2016). The dilemma of juvenile delinquency among government secondary schools in Jema'a local government area of Kaduna State Nigeria. International Journal of Academic Research in Education and Review, 4(3), 96-102. .

14. Balda, S., Sangwan,. S., \& Kumari, A. (2019). Family. Environment as perceived by Adolescent boys and girls. International Journal of Current Microbiology and Applied Sciences, 8(1), 22622269.

15. Alemika, E. E., \& Chukwuma, I. (2001). Juvenile justice administration in Nigeria: Philosophy and practice. Lagos: Centre for Law Enforcement Education.

16. Zakari, A. W. (2012). Juvenile justice administration in Nigeria: A case study of Kogi State. Published Thesis for the award of Masters of Law. Ahmadu Bello University, Zarja, Nigeria.

17. Ekpenyong, 'N.S., Raimi, L., \& Ekpenyoug, A. S. (2012). Urban poverty and juvenile delinquency in Nigeria: Through the lens of Port Harcourt remand home inmates. Research on Huthànities'and Social Sciences

18. Umair, A., \& Azka, M. (2016). Factorš affecting juvenile delinquency in Punjab, Pakistan: A case study conducted at juvenile prisons in Punjab province. Mediterranean Journal of Social Sciences, 7(4), 372-379.

19. Shoemaker, D.J. (2009). Juvenile delinquency. Rowman and Little field Publishers.

Cite This Article: Iseberetonma, Victor \& Elem, Maduawuchi (2021). Home Environment and Juvenile Delinquency in Nigeria: A Study of Inmates in Port Harcourt Remand Home and The Borstal Institute, Ilorin in Kware State. EAS J Humanit Cult Stud, 3(2), 70-78. 